\title{
DE GUSTIBUS NON EST DISPUTANDUM
}

\section{DE GUSTIBUS NON EST DISPUTANDUM}

The beauty is the brightness of the truth, that means architecture shuld be beautiful, too. It is the mirror of our life.

Podczas rozmów o architekturze przeprowadzonych dla miesięcznika Archivolta Krzysztof Lenartowicz zapytał mnie: Czym jest dobra architektura? Odpowiedziałem: „Ona musi być piękna”. Jakie bowiem zainteresowanie może budzić choćby nie wiem jak cudownie trwała i nadzwyczajnie użyteczna architektura, jeśli nie będzie również i przede wszystkim, piękna? No właśnie: żadne. Tutaj należałoby oczywiście wyjaśnić filozoficzny i estetyczny dyskurs dotyczący definicji piękna: jeżeli piękno jest tym, co stanowi duchowe szczęście człowieka/społeczeństwa, to skoro ludzie są różni i w różny sposób swoje szczęście osiągają, nie może być jednej, dla wszystkich aktualnej, piękności. Będą się one różniły z epoki na epokę, z kultury na kulturę, od jednostki do jednostki. Jednak nawet wtedy istnieje zasadnicza zgodność co do piękna. Bowiem już Tomasz z Akwinu trafnie napisał, że „Piękno polega na pewnym blasku i proporcji” (Pulchram consistit in quadam claritate et proportione).

Takie rozumienie ,proporcji i blasku” wskazuje, że według Tomasza z Akwinu o pięknie stanowił zarówno wygląd rzeczy jak i ich istota. W starożytności piękno znaczyło to samo, co dobro. A Tomasz z Akwinu również wyjaśnił, że dobro jest przedmiotem pragnienia, a piękno - poznania. Ale implikował tez, że piękno tkwi w samych rzeczach, nie zaś, jak według wielu teorii średniowiecznych, w ich znaczeniu alegorycznym. Starożytni posługiwali się szerokim pojęciem piękna: $w$ myśli tego pojecia pięknem było wszystko, co jest cenne, a zarazem pociąga i budzi zadowolenie. Zaś Witruwiusz ujął to między innymi w kategoriach: Przy budowie należy uwzględniać: trwałości, celowość i piękno (firmitas, utilitas, venustas). Piękno będzie zapewnione, jeśli wygląd budowy będzie miły i wykwintny, a wymiary poszczególnych członów oparte na właściwych zasadach symetrii.

Tyle o pojęciu piękna w krótkim opisie od początku historii/teorii estetyki architektury naszego kontynentu. (Abendlandes).

Ongiś zapytano A. Dürera: „Piękno, co to jest, nie wiem, chociaż wiele rzeczy to posiada". Kryterium piękna leży dla Dürera między satysfakcją i przeciętnością, ale przede wszystkim w porównaniu stosunku jakości i ilości.

Rozpatrzmy jeszcze kilka pojęć - piękna - w tendencjach przełomu ubiegłego stulecia na początkach modernizmu:

- Le Corbusier uważa, że geometryczne formy są formami pierwotnymi, ekonomiczne i również piękne, które zarazem zadowalają naszą duszę.

- Zaś L. I. Kahn próbuje w swoich teoretycznych myślach o naturze, porządku i geometrii, przedstawić architekturę jako wyrażenie ludzkich życzeń, które przedstawiają nasz sposób życia w danej epoce $i$ jest jego zdaniem wynikiem prawdy. A więc można by było $z$ tego wnioskować, że architektura/projekt powinna być również piękna-y. To stwierdzenie było dla nas/dla mnie, zawsze klasyczne!

Prawdopodobnie do tej pory nie spotykało się takiego zagadkowego potraktowania genezy estetycznej jakości wywodzącej się z konstrukcji i funkcjonalizmu.

* Scholz Stefan, dipl. ing. arch., Berlin, Politechnika Poznańska, Wydział Architektury. 
Przy tym wystarczy spojrzeć na niektóre wyniki naszych poczynań, niektórych twórców/architektów /urbanistów w naszym środowisku/w naszym otoczeniu. Niestety jesteśmy coraz częściej konfrontowani z przerażającymi wynikami tego stwierdzenia, (pełen szpetności), która zaprzecza naszym postawionym tezom, piękna i marzenia, że architektura/projekt powinien być - piękna-y!

Można zaobserwować, że to pojęcie piękna w architekturze współczesnej, powiedzmy, gdzieś od połowy ubiegłego stulecia, skończyło się!!! Minęto stulecie przenikające się dążeniem do głębokiej historycznej wiedzy i nauki, technicznych wynalazków, nowych materiałów jak i coraz szybszej komunikacji, która pozostawia u nas szybko zmieniające się obrazki. W budownictwie uzyskano mniemanie: wszystko da się zrealizować/zrobić, które umożliwiło i pozostawia coraz częściej wrażenie błahości i utraty sensotwórczości jak i braku boskiej finezji. Niestety spotykamy coraz częściej pewną stratę o czym dawniej nikt nie mówit, i nie zastanawiał się, ponieważ było to zawsze oczywiste w naszych zmysłach, tzw.: poczucie masy, zgodność ze skalą i w proporcji jak i wyczucie piękna.

Ta dawna oswojona/utkwiona naturalność dobrego gustu, piękności i myślenie, bazujące na praktyce i wiedzy, była przeszczepiana/transponowana z generacji na generację. Ona została coraz bardziej utracona i to tak, że trzeba by jej na nowo się uczyć /tworzyć? To tzw. wyczucie - z pustego żołądka nie wystarcza, wręcz przeciwnie, ono błądzi! Niektórzy myślą zaś, że można na niej bazować, ponieważ jest to wygodne i nie sprawia trudności w tworzeniu. Niestety to można wszędzie na tzw. szpetnościach obserwować, która się spotyka w naszym budowanym świecie.

„Dobry Gust”, stwierdził ongiś Adorno - jest drogim sejsmografem historycznego doświadczenia Ale zapytajmy: Co to jest ten „dobry gust”? lub pomyślimy sobie, hm: ....albo ktoś to posiada, lub też nie!...
Haha,ha! Kto nam powie, co to jest ten dobry gust? Z pewnością ogarnie tutaj wielu potężny śmiech. Lub będzie to też uważane za ogólną arogancję czy też elitarność, która próbuje nam opisać, co to jest dobry gust/wyczucie piękna? Często słyszymy werdykt: pozostawmy wreszcie tę tzw. tezę - dobrego smaku/ gustu - ludziom, skoro oni są również obecnie szczęśliwi! Ale - chwileczkę! Przecież zauważmy, czemu nie trzeba zaprzeczać, że utraciliśmy coraz bardziej naszą tzw. nieświadomą estetyczną wrażliwość.

Jak już wspomniałem, od połowy ubiegłego stulecia obserwujemy utratę tej estetycznej świadomości, która narodziła tzw. eksperta, fachowca detali i specjalistę. Niektórzy twierdzą nawet, że dobry gust /smak jest przecież prywatną sprawą? Co za kardynalny błąd!!! ... „De gustibus non est disputandum”. Już dawni Rzymianie tym stwierdzeniem bronili swojego parweniuszostwa przed kpinami Greków i zostało to do dzisiaj dewizą każdej obrony przed słabym gustem lub wyczuciem piękna. Trzeba również stwierdzić, że pomiędzy - dobrym gustem - a - niedobrym gustem - są diametralne różnice!!! Dobry gust, albo wyczucie piękna, nie jest tylko poczuciem, lecz ustala osąd/werdykt o czymś.

On polega/bazuje na wiedzy, znajomości rzeczy a wiec na cechach rozróżniania, która wymaga głębokich informacji, bo wpierw, gdy posiadam informacje i wiedzę jak i głęboką świadomość czegoś, mogę sobie wytworzyć dobry gust/piękno i jestem od tego czasu dopiero dojrzały, by wydać sąd o rzeczach, o czymś!

A więc, piękno jest duchowym szczęściem, które człowieka chroni, broni i pobudza. Ale jakie cechy powinna posiadać jakaś rzecz, budynek/architektura, czy miasto, aby wyrazić piękno? Tak, - piękno jest wartością dodatkową, która znajduje się w głębi każdej dobrej rzeczy, dobrze zrobionego budynku/ architektury. Ona musi być od początku formułowana/kształtowana. Ona musi każdą fazę pracy każde- 
go urbanisty, architekta, przenikać i ogarniać. Aby piękno wyrazić, trzeba wpierw znaleźć odpowiedni umiar, by potem go zastosować przy kształtowaniu. Dlatego nie powinniśmy pozostawić jakiejkolwiek dowolności w tej tak ważnej dziedzinie - estetyce. Sztuka jest produktem ludzkiej tęsknoty i inspiracji, przekracza granice logiki i rozsądku. Ona jest wspólnym problemem, który nas wszystkich dotyczy, ponieważ: „Piękno” jest odwieczną potrzebą każdego cywilizowanego człowieka! Ażeby odpowiedzieć na postawione pytania w tezach Konferencji np.: Czy piękno zostało zastąpione $\mathrm{w}$ architekturze innymi kategoriami estetyki? pozwolę sobie odpowiedzieć anegdotką, którą przeżyłem osobiście:

...Po zwiedzaniu tzw. Targów Nieruchomości (MIPIM) w Cannes (Francja) z inwestorem i w towarzystwie mojej żony, ogarnęła mnie jakaś głęboka mdłość, ból głowy i rezygnacja, a więc postanowitem od razu pojechać do Vals, aby w termach projektu arch. P. Zumthora wypocząć i przejść znowu do wyczucia piękna, żona zaś pojechała do Wenecji, aby wypić porządne espresso macchiato na Placu Św. Marka w "Cafe Florian” i przejść znowu w uczucie piękna i poczuć że znajduje się w najpiękniejszym salonie świata w otoczeniu pięknej architektury!!! Haha,ha!

Dla mnie - piękno - wyraża się w następujących przykładach, które spotykałem w następujących bu- dynkach/architekturze lub założeniach urbanistycznych, które Pars pro Toto stoją dla wielu innych, aby tutaj tylko kilka wymienić:

- Piramidy egipskie; - Propyleje ateńskie; - w założeniach Willi Hadriana w Tivoli;

- ruiny Term Caracalli w Rzymie; - Castel del Monte w Apulii; - kościoły romańskie; - Piazza Navona w Rzymie; - Alhambra w Grenadzie; - Meczet w Cordobie; wnętrze i magazyn Biblioteki Saint-Genevieve w Paryżu, arch H. Labrouste; - Maison de Verre, Paryż, arch. P. Chareau i B. Bijvoet.

we współczesnej architekturze:

- Casa Malaparte na wyspie Capri, arch A. Libera;

- Ratusz w Säynätsalo, arch. A. Aalto.

- Klasztor La Tourette w Eveux-sur-Abrasle, arch.

Le Corbusier;

- Salk Instytut w La Jolla, arch L.I. Kahn;

- Cmentarz Brion, w San Vito di Altivole, arch.

C. Scarpa.

w ostatnich realizacjach:

- Douglas Hause, Harbor Springs, Michigan, arch.

R. Meier.

- Dom jednorodzinny w Riva San Vitale, arch. M. Botta:

- Termy w Vals, arch P. Zumthor:

- japońskie ogrody.

i last but not least:

- Krematorium w Berlinie-Treptow, mojego byłego partnera i przyjaciela, arch. A. Schultesa.

\section{BIBLIOGRAFIA}

Archivolta, 2/6/2000 kwiecień-czerwiec 2000.

W. Tatarkiewicz, Historia Estetyki I, Wydawnictwo Ossolińskich 1962.

V. M. Lampugnani, Die Modernität des Dauerhaften, Essays zu Stadt, Architektur und Design, Verlag K. Wagenbach, Berlin 1995.

M. Sack, Von der Utopie, dem guten Geschmack und der Kultur des Bauherrn, oder: Wie entsteht gute Architektur? wyd, Architekturforum im Touringhaus, $\mathrm{CH}-4500$ Solothurn. E.Ullmann, Die Lehre von den Proportionen, Verlag der Kunst, Dresden,1958.

W. Gropius, Architektur, Fischer Bücher, Frakfurt am Main 1959. Foto z kolekcji arch. A.Schultes, Ch. Frank./fotografowie: Huthmacher, Schwarz.

Cytaty łacińskie: z Duden das Fremdwörterbuch, Band 5, Dudenverlag, Mannheim, Leipzig, Wien, Zürich 1997. 